\title{
Antitrust and Marketing: A Primer and Call to Research
}

\author{
Gregory T. Gundlach, Joan M. Phillips, and Debra \\ M. Desrochers
}

\begin{abstract}
A s a body of public policy thought, antitrust is concerned with the competitive consequences of conduct by organizations engaged in exchange. Its principles and doctrine ensure that exchange is conducted in a way that benefits from the incentives and discipline of a competitive marketplace. From an antitrust perspective, safeguarding competition yields a well-functioning and prosperous economic system. Competition is considered the best means of eliminating excess profits; efficiently allocating resources; forcing firms to produce quality goods at the lowest costs, in amounts consumers want; and stimulating innovation to enhance the overall welfare of consumers (Shenefield and Stelzer 2001, p. 13).
\end{abstract}

\section{Antitrust's Economic Foundations}

Modern antitrust relies extensively on microeconomics, particularly price theory, to understand competition and the nature of exchange. Although the Supreme Court has not endorsed an economic interpretation of antitrust's principle concept, consumer welfare, a largely economic approach to antitrust has been adopted by the federal agencies and most courts. Advocates of an economic approach contend that consumer welfare should be conceived of as "economic efficiency" (Bork 1993). According to these advocates, the careful definitions and parsimonious logical structure of economics yields the required intellectual rigor for understanding competitive behavior and for evaluating practices that jeopardize economic efficiency.

Although many scholars and policymakers endorse an economic view of consumer welfare, the nature of economic theory best suited to inform antitrust is currently under debate (Jacobs 1995; see also Peritz 2002). Two schools of thought dominate this debate (see Gundlach 2001).

\section{Chicago School of Antitrust}

The Chicago School holds to the core belief that markets, by their nature, tend toward efficiency and that market imperfections are generally transitory in nature and, for the most part, self-correcting (Posner 1979). Adopting assumptions that reflect this view and working from a model of perfect competition originating in neoclassical price theory, much of the competitive conduct that poses ambiguous implica-

Gregory T. Gundlach is John W. Berry Sr. Professor of Business, Mendoza College of Business, University of Notre Dame, and Senior Research Fellow, American Antitrust Institute. JoAN M. PhILlips is Assistant Professor of Marketing, and DebrA Desrochers is Assistant Professor of Marketing, Department of Marketing, Mendoza College of Business, University of Notre Dame. The authors graciously acknowledge the contribution of all the workshop and conference participants for their insightful comments and future research directions. tions for the welfare of consumers is considered the manifestation of efficient market behavior. The consequences of the Chicago School for antitrust are to provide clarity in the administration of antitrust and rationalize antitrust enforcement. By defining behavior purely in terms of output and price, enforcement authorities and the courts are viewed to be equipped with simple and objective tests for thoroughly determining the effect of marketplace conduct on consumer welfare. Whereas expanded output and lower prices are considered to enhance consumer welfare, restraints on output and higher prices are considered to diminish consumer welfare.

\section{Post-Chicago School of Antitrust}

In contrast to the Chicago School, proponents of the postChicago School view markets as largely imperfect with market failures not necessarily self-correcting (Baker 1989; Hovenkamp 1985). According to this school of thought, firms can and do take advantage of market imperfections that lead to inefficient outcomes. This thinking extends from progressive changes in the field of industrial organization economics (Jacobs 1995). During the 1980s, focus shifted from industry structure, conduct, and performance for understanding competition to the study of strategic behavior by firms in imperfectly competitive markets. A host of new approaches for analyzing central antitrust questions informs this new generation of thought (Ordover and Saloner 1989). These approaches go beyond simple price theory to include game-theoretic and other perspectives for explaining firm behavior. Together, they reflect a very different view of human nature, firm behavior, and efficiency of the marketplace (Porter 1991). In contrast to the Chicago School, market imperfections, such as information asymmetry, are considered a pervasive and durable phenomenon. Such imperfections corrode market efficiencies over time and are employed by strategic firms to accentuate, perpetuate, and exploit their market position and, at times, hamper competitive balance (Baker 1989; Kaplow 1985). The resultant belief is that antitrust enforcement must be more active, through heightened scrutiny of a wider range of marketplace conduct to ensure consumer welfare (Ross 1992).

\section{Consequences for Antitrust Practice}

The key differences between the Chicago School and the post-Chicago School pose contrary implications for antitrust practice (Hovenkamp 1985). Under the Chicago School, the generally simple principles of neoclassical price theory offer a coherent set of explanations that can be easily applied by the courts. These simple principles, however, have been increasingly challenged on the grounds that they do not reflect the reality of the marketplace. Alternately, the more complicated models of the post-Chicago School are argued 
to be more comprehensible, but admitted to be more complex in their methodology (Arthur 1994).

\section{Emergence of Antitrust as an Interdisciplinary Field}

A growing view is that contributions from other disciplines may further extend antitrust's development (Gundlach 2001). In itself, the post-Chicago School of antitrust reflects a growing understanding of the breadth of theory applicable to antitrust. Scholars from various fields have increasingly suggested that antitrust should recognize its interdisciplinary foundations (Scheffman 1996). These scholars contend that additional knowledge beyond economics is required to address the complexities of competitive conduct, from sources such as the other social sciences, the humanities, and traditional legal analysis (Gerla 1985, Sullivan 1977; see also White 2002).

Several recent events suggest a movement toward antitrust as an interdisciplinary field. For example, beginning in Eastman Kodak Company v. Image Technical Services Inc. (1992), the Supreme Court announced rules that required a more fact-based and empirical approach to antitrust, versus the simplified methodology and deductive approach of the Chicago School. Similarly, in Brook Group Ltd. v. Brown and Williamson Tobacco Corporation (1993), the Supreme Court again announced its requirement of a more factually intensive approach to antitrust. Together, these pronouncements suggested the beginning of the Court's shift away from the abstract deductive generalities of the Chicago School approach to the more open, factintensive analysis promoted by the post-Chicago School (Sullivan 1995). Decisions of the lower courts, though not fully consonant, similarly reflect this shift. Beyond these pronouncements and decisions, an increasing number of high-profile cases brought by both the Department of Justice and the Federal Trade Commission have also evidenced a movement toward post-Chicago thinking and an interdisciplinary understanding of competition. Finally, a trend toward the broadening of antitrust's academic foundations is also detectable in the antitrust literature (Gundlach 2001).

\section{Marketing and Antitrust}

Marketing is a key repository of knowledge that is capable of contributing to the further development of antitrust. As an offspring of economics, marketing provides a basis for understanding how firms compete by studying the thinking of managers and the motivations and purchase patterns of consumers. As an academic discipline, one of marketing's primary objectives is to describe and understand (and at times predict) the manner in which firms and consumers engage in exchange to meet individual needs and organizational goals.

\section{Nature of Marketing}

As applied in antitrust, the aggregate focus of industrial organization economics encompasses the behavior of the firm within the context of the larger market. Marketing as the "science of exchange" complements this perspective by adding emphasis on the individual actor (i.e., manager or consumer). The marketing management process (i.e., analy- sis, planning, implementation, and control) thus provides a lens through which the fine-grained detail of transactions between actors-as well as the behavioral nuances that take place as part of the exchange process-can be viewed (see also Gundlach and Phillips 2002; Sullivan 2002). For antitrust, the complementary nature of marketing's emphasis on the actors provides a key basis for more fully understanding the nature of competitive conduct and the welfare of consumers. The insights provided by joining these disciplines can capture the dynamic efficiencies that characterize a vibrant, innovative economy (see also Foer 2002).

\section{Call to Research}

Although some antitrust stakeholders have recognized the benefits of integrating insights from marketing into the discipline of antitrust, this progression remains in the early stages. In this regard, a key design objective for Notre Dame's Workshop and Conference on Marketing Competitive Conduct and Antitrust Policy was to begin integrating these fields. During the final session, participants brainstormed to identify research opportunities for the integration of marketing insights into antitrust and to chart a course for further research. The interaction of members from both the antitrust community and the marketing discipline led this session to be particularly fruitful. The research opportunities generated by employing the analytic model for antitrust analysis as an organizing framework (see Shenefield and Stelzer 2001, pp. 30-36) are briefly described next.

\section{Consumer Welfare: Economic Efficiency and Beyond}

Consumer welfare, the key variable of interest in antitrust, is considered by many antitrust stakeholders to be conceived exclusively in terms of static economic efficiency and more particularly allocative and productive efficiency (for a review, see Hovenkamp 1999, pp. 74-76 ). One benelit of defining consumer welfare narrowly and in efficiency terms is that it permits the application of a unified and parsimonious theory (e.g., neoclassical price theory) to the important questions of antitrust. However, some scholars in antitrust have called for conceptions of consumer welfare that explicitly include a dynamic view of competition and, in particular, benefits extending from innovation (e.g., Sullivan and Grimes 2000, p. 602). Furthermore, others contend that, beyond efficiency (both static and dynamic efficiency in the form of innovation), consumer variety and choice are also important dimensions of consumer welfare (e.g., Averitt and Lande 1997; see also Guiltinan 2002; Petty 2002).

Although modern marketing can be both macro and micro in its perspective, it tends to focus on the welfare needs of individual consumers as opposed to consumers in the aggregate. A key question is, How will the insights gleaned from the disaggregate perspective help further antitrust's understanding of consumer welfare at the aggregate level? Another key question extends from the debate in antitrust surrounding the strictly efficiency-based perspective of consumer welfare, versus a more broadly conceived notion of consumer welfare. Given the existing efficiency-based conceptions of consumer welfare, could marketing provide useful insights to better understand allocative and productive 
efficiencies? Beyond economic efficiency, could marketing be helpful in identifying and understanding the importance of other dimensions of consumer welfare? What operationalizations could be developed? In this regard, the attendees identified the conception and operationalization of consumer welfare as rich areas of opportunity and proposed stakeholder analyses from marketing and strategic management areas as a potential basis for structuring and examining the nature of consumer welfare (see Hawker 2002).

\section{Market Definition: The Relevant Arena of Competition}

A relevant market in antitrust defines the competitive arena in which questions regarding consumer welfare are both posed and answered. The determination of the relevant market is critically important in the antitrust process, because it affects the assessment of whether a firm competing in the market possesses the ability to reduce competition and therefore harm the welfare of consumers. A more widely defined market, containing a greater number of competitors, dilutes this potential, as the competitor's contributions to competition are more broadly distributed. A more narrowly defined market, containing few competitors, concentrates this distribution and therefore enhances the competitor's potency in relation to competition (for a review, see Sullivan and Grimes 2000, pp. 61-65). Defining the relevant market in antitrust involves attempting to understand the reasonable interchangeability and the actual substitution of competitor's goods and services by consumers (Shanefield and Stelzer 2001, p. 31). Given antitrust's reliance on price theory, extant approaches in antitrust tend to focus on considerations of interchangeability and substitution from the perspective of price and more particularly price elasticity of demand (Sullivan and Harrison 1998, pp. 30-31). Other nonprice related factors are also considered, but if the price data are available, emphasis is given to price (see Hovenkamp 1999, p. 126).

Given the consumer focus of market definition and marketing's long-standing emphasis on understanding consumers, a key question is whether a better understanding could be obtained through the application of marketing insights. What marketing insights seem most relevant? What roles does marketing play in the consumer decision process? For example, does marketing itself influence consumers' perceptions in relation to the products they might consider as interchangeable or as substitutes? What implication accompanies the distinction of consumers perceiving product substitutes in terms of the functional and nonfunctional benefits (see Kotler 2003, p. 11)? This vigorous discussion generated many ideas, and market definition was considered another area in which marketing's contributions to antitrust may be particularly beneficial.

\section{Market Power: The Ability to Reduce Competition}

Market power in antitrust is defined as the ability of a competitor to profitably raise price above competitive levels in a defined market and is intended to reflect the more general concept of the ability to reduce competition (Hovenkamp 1999, p. 79). In this sense, the assessment of market power serves as a basis for understanding whether a competitor possesses the threshold ability to harm competition and potentially injure consumer welfare. The assessment of market power therefore is an important aspect of antitrust's analytic process. The sources of potential market power in antitrust have mainly been conceived of in terms of the ability to reduce competition that arises from resource concentration in a defined market and, more particularly, the dominance of a single competitor (or group of competitors acting together) in the market (Sullivan and Harrison 1988, p. 27). For this reason, unilateral activity such as monopolization and collusion, in the form of conspiracy or extending from merger, is of particular interest in antitrust. Another source of potential market power now being considered in antitrust is the ability to reduce competition that arises from information asymmetry. Extending from an understanding of competition as a dynamic process, information asymmetries are potentially exploitable in ways that enable a firm to exercise market power.

Marketing possesses a long history of focus on and study of the nature of power in exchange, including sources of power, power as a concept, and the exercise of power and interdependence and their implications in exchange relationships (e.g., Frazier and Rody 1991; Gaski 1984; Geyskens, Steenkamp, and Kumar 1999; Gundlach and Cadotte 1994). Could such an understanding in marketing be brought to bear on an understanding of market power in antitrust? Could other sources of power be identified that would have relevance to antitrust? Given the potential impact of market power on a competitive marketplace, the participants considered this area a priority for further research in antitrust.

\section{Competitive Conduct: Horizontal and Vertical Behavior in Exchange}

Antitrust contemplates the exercise of market power and its implications for consumer welfare in terms of both horizontal (e.g., competitive) and vertical (e.g., distribution) exchange conduct. Horizontal conduct has the potential to affect competition directly because it involves competitors and is generally well understood. However, vertical conduct's potential impacts on consumer welfare are less understood. For example, in regard to vertical relationships, the consumer welfare implications of the upstream channel member's power over the downstream member are well understood. However, the reciprocal relationship (when the downstream channel member holds and exercises power over its upstream suppliers) is not as well-developed. Historically, the locus of power in distribution relationships was held by manufacturers and other upstream channel suppliers, but more recently, power has shifted to the downstream channel members. Some slotting practices are indicative of this power shift (Bloom, Gundlach, and Cannon 2000; see also Balto 2002; Wilkie, Desrochers, and Gundlach 2002).

As a discipline, marketing relies on the marketing management process (i.e., analysis, planning, implementation, and control) to produce competitive exchanges of superior customer value (Bagozzi 1975; Houston and Gassenheimer 1987). Indeed, marketing's most famous axiom, the marketing concept, holds that the key to being successful in satisfying customer needs and organizational goals is to use the marketing process to deliver customer value more effectively than competitors do (Kotler 2003, p. 9). Could this orientation provide insights for antitrust's understanding of 
competitive conduct? What particular insights could prove to be helpful for enriching antitrust's understanding of competitive conduct overall? With respect to horizontal conduct? Vertical conduct? Conduct by upstream channel members? By downstream channel members? Could a marketing understanding provide a basis for identifying new forms of conduct not yet known to antitrust? Given marketing's deeper understanding of channels and interorganizational relationships, the discussants believed that antitrust could benefit from marketing's understanding of interfirm relations and study of vertical marketing systems.

\section{Welfare Implications: The Consequences of Competitive Conduct for Consumer Welfare}

The key analytic challenge in antitrust involves understanding the linkage of competitive conduct to consumer welfare. Relying on efficiency-based conceptions of consumer welfare and the principles of neoclassical price theory, antitrust focuses mainly on output and its obverse price to understand the implications of competitive conduct. Although additional considerations attend this inquiry, assessments of output and price provide a straightforward approach for assessing consumer welfare in terms of economic efficiency. Conduct that results in a reduction of output (and, therefore, higher prices) in a defined arena of competition, with barriers to entry and without sufficiently offsetting and compelling efficiencies, is deemed anticompetitive.

From this perspective, a key question is whether insights from marketing can enhance antitrust's approach to understanding the implications of competitive conduct for consumer welfare. Furthermore, within the context of consumer welfare, can marketing insights enhance the understanding of the efficiencies and inefficiencies of competitive conduct? Can marketing enhance antitrust's understanding of the link between consumer welfare and allocative efficiency? Productive efficiency? Can marketing help identify the nature of and quantify the losses in consumer welfare from allocative inefficiencies? The nature and gains in consumer welfare from productive efficiencies? The discussants also stated that marketing's deep and rich literature in the behavioral aspects of pricing could supplement many of the currently held economic assumptions used for understanding consumer welfare.

\section{Remedies: Ensuring and Restoring Competition and Consumer Welfare}

Remedies serve two functions in antitrust. First, they attempt to restore competition and consumer welfare to a standard that existed before any reduction and damage. Second, they ensure that competition and consumer welfare are not reduced or undermined by future conduct. Remedies can involve divestitures in the context of merger enforcement or punitive monetary and/or nonmonetary requirements and sanctions stemming from litigation or administrative proceedings (Sullivan 1977, pp. 141-149). As part of the antitrust process, the construction and implementation of remedies are particularly important, because their poor design or implementation can potentially cause more harm than the conduct they are intended to address. Remedies require a comprehensive understanding of the nature of competition and its relationship to consumer welfare in a particular market. For this reason, many of the questions identified previously for the other areas of the antitrust process are also applicable to remedies.

Additional key issues include whether marketing and its disaggregate understanding of competition and consumers can enhance the understanding, design, implementation, and management of antitrust remedies. Can marketing insights assist in the identification of firms for divestitures in merger evaluations? Can marketing assist in the understanding of the likely consequences of a divestiture? Can a marketingbased understanding of consumers help in constructing consumer-based remedies? In addition to these topics, the participants discussed how the contributions identified in the previous sections could lead to additional insights to antitrust's understanding of remedies.

\section{References}

Arthur, Thomas C. (1994), "The Costly Quest for Perfect Competition: Kodak and Nonstructural Market Power," New York University Law Review, 69 (1), 1-61.

Averitt, Neil W. and Robert H. Lande (1997), "Consumer Sovereignty: A Unified Theory of Antitrust and Consumer Protection Law," Antitrust Law Journal, 65 (3), 7I3-57.

Bagozzi, Richard P. (1975), "Marketing as Exchange," Journal of Marketing, 39 (October), 32-39.

Baker, Jonathan B. (1989), "Recent Developments in Economics That Challenge Chicago School Views," Antitrust Law Journal, $58,645-55$.

Balto, David A. (2002), "Recent Legal and Regulatory Developments in Slotting Allowances and Category Management," Journal of Public Policy \& Marketing, 21 (Fall), 289-94.

Bloom, Paul N., Gregory T. Gundlach, and Joseph P. Cannon (2000), "Slotting Allowances and Fees: Schools of Thought and the Views of Practicing Managers," Journal of Marketing, 64 (April), 92-108.

Bork, Robert H. (1993), The Antitrust Paradox: A Policy at Wat with Itself, $2 \mathrm{~d}$ ed. New York: Basic Books, Inc.

Brooke Group Lid. v. Brown \& Williamson Tobacco Corp. (1993). 113 S. Ct. 2578.

Eastman Kodak Co. v. Image Technical Services, Inc. (1992), 112 S. Ct. 2072.

Foer, Albert A. (2002), "The Third Leg of the Antitrust Stool," Journal of Public Policy \& Marketing, 21 (Fall), 227-31.

Frazier, Gary L. and Raymond C. Rody (1991), "The Use of Influence Strategies in Interfirm Relationships in Industrial Product Channels," Journal of Marketing, 55 (January), 52-69.

Gaski, John F. (1984), "The Theory of Power and Contlict in Channels of Distribution," Journal of Marketing, 48 (Summer), 9-29.

Gerla, Harry S. (1985), "The Psychology of Predatory Pricing: Why Predatory Pricing Pays," Southwestern Law Journal, 39 (3), 755-80.

Geyskens, Inge, Jan-Benedict E.M. Steenkamp, and Nirmalya Kumar (1999), "A Meta-Analysis of Satisfaction in Marketing Channel Relationships," Journal of Marketing Research, 36 (May), 223-38.

Guiltinan, Joseph P. (2002), "Choice and Variety in Antitrust Law: A Marketing Perspective," Joumal of Public Policy \& Marketing, 21 (Fall), 260-68. 
Gundlach, Gregory T. (2001), "Marketing and Modern Antitrust Thought," in Handbook of Marketing and Society, Paul N. Bloom and Gregory T. Gundlach, eds. Thousand Oaks, CA: Sage Publications, Inc., 34-50.

and Ernest R. Cadotte (1994), "Exchange Interdependence and Interfirm Interaction: Research in a Simulated Channel Setting," Journal of Marketing Research, 31 (November), 516-32.

- and Joan M. Phillips (2002), "Marketing in Antitrust: Contributions and Challenges," Journal of Public Policy \& Marketing, 21 (Fall), 250-53.

Hawker, Norman W. (2002), "The Public Policy of Antitrust and Strategy: An Overview," Journal of Public Policy \& Marketing, 21 (Fall), 257-59.

Houston, Franklin S. and Jule B. Gassenheimer (1987), "Marketing and Exchange," Journal of Marketing, 51 (October), 3-18.

Hovenkamp, Herbert (1985), "Antitrust Policy After Chicago," Michigan Law Review, 84 (November), 213-84.

(1999), Federal Antitrust Policy: The Law of Competition and Its Practice, Hornbook Series. St. Paul, MN: West Group Publishing Co.

Jacobs, Michael S. (1995), "An Essay on the Normative Foundations of Antitrust Economics," North Carolina Law Review, 74 (1), 219-66.

Kaplow, Louis (1985), "Extension of Monopoly Power Through Leverage," Columbia Law Review, 85 (3), 515-56.

Kotler, Philip (2003), Marketing Management, 11 th ed. Upper Saddle River, NJ: Prentice Hall.

Ordover Janusz A. and Garth Saloner (1989), "Predation, Monopolization, and Antitrust," in Handbook of Industrial Organization, Richard Schmalensee and Robert D. Willig, eds. Amsterdam: Elsevier Science Publishers, 537-96.

Peritz, Rudolph J.R. (2002), “Antitrust Policy and Aggressive Business Strategy: A Historical Perspective on Understanding Commercial Purposes and Effects," Journal of Public Policy \& Marketing, 21 (Fall), 237-42.

Petty, Ross D. (2002), “Limiting Product Choice: Innovation, Market Evolution, and Antitrust," Journal of Public Policy \& Marketing, (Fall), 269-74.
Porter, Robert H. (1991), “A Review Essay on Handbook of Industrial Organization," Journal of Economic Literature, 29 (June), 553-72.

Posner, Richard A. (1979), "The Chicago School of Antitrust Analysis," University of Pennsylvania Law Review, 127, 925-52.

Ross, Stephen (1992), "Post-Chicago Analysis After Kodak: Interview with Professor Steven C. Salop," Antitrust, (Fall/Winter), 20-22.

Scheffman, David T. (1996), "Antitrust, Economics, and 'Reality," in The Economics of the Antitrust Process, Malcolm B. Coate and Andrew N. Kleit, eds. Boston: Kluwer Academic Publishers, 239-54.

Shenefield, John H. and Irwin M. Stelzer (2001), The Antitrust Laws: A Primer, 4th ed. Washington, DC: AEI Press.

Sullivan, E. Thomas and Jeffrey L. Harrison (1998), Understanding Antitrust and Its Economic Implications, 3d ed. New York: Matthew Bender.

Sullivan, Lawrence A. (1977), "Economics and More Humanistic Disciplines: What are the Sources of Wisdom for Antitrust?" University of Pennsylvania Law Review, 125, 1214-43.

(1995), "Post-Chicago Economics: Economists, Lawyers, Judges, and Enforcement Officials in a Less Determinate Theoretical World," Antitrust Law Journal, 63 (2), 669-81.

- and Warren S. Grimes (2000), The Law of Antitrust: An Integrated Handbook, Hornbook Series. St. Paul, MN: West Group Publishing Co.

Sullivan, Mary (2002), "The Role of Marketing in Antitrust," Journal of Public Policy \& Marketing, 21 (Fall), 247-49.

White, Lawrence J. (2002), "Business School Economics and Antitrust: What's Thought and What's Taught, " Journal of Public Policy \& Markering, 21 (Fall), 254-56.

Wilkie, William L., Debra M. Desrochers, and Gregory T. Gundlach (2002), "Marketing Research and Public Policy: The Case of Slotting Fees," Journal of Public Policy \& Marketing, 21 (Fall), 275-88. 
Copyright of Journal of Public Policy \& Marketing is the property of American Marketing Association and its content may not be copied or emailed to multiple sites or posted to a listserv without the copyright holder's express written permission. However, users may print, download, or email articles for individual use. 